測定管は長さ $10 \mathrm{~cm}$, 内径 $20 \mathrm{~mm}$ の円筒で, 端に $4 \mathrm{~mm}$ 径孔 7 個, $2 \mathrm{~mm}$ 径孔 3 個を有する.

a. 圧気速曲線：測定管の特性曲線は curvilinear で, 臨床例の通気曲線に近似するが，曲率などが多少異な る. 今後測定管改良により，管特性曲線を鼻腔のそれに 酷似させ得る。

b. 対数グラフ：測定管特性曲線上の各点を描点する と, 人間の圧気速曲線の場合と同様に限界速度を境にし た 2 本の直線よりなる。

3. 測定法の実際

高価な装㯰一切不要のポータブルセッッを作製し呈示 した，番マスク（市販麻酔導入用 1 号， 2 号）と測定管
の間に三連管の中央管を，口内圧チューブを一側端管に 接続。他端管は開放とし，マスク装着して安静呼吸をさ せて中央管水柱の呼吸に伴う恋動を観察する。

測定管端の孔を開閉して水柱変動が無い所を求める と，その際の孔の面積が求める值である．備付の換算表 から被検者の鼻腔有効断面積值が求められるし，呼吸圧 変化 (端の水柱変動值) を読取ると, 得られた断面積值 における測定管の特性曲線から気速值も判る. 従つて安 静呼吸における最大流速点の抵抗値 $\mathrm{R}=\frac{\mathrm{P}}{\dot{\mathrm{V}}}$ が求められ る.

以上鼻腔有効断面積測定法の簡易性と有用性（評価） について述べた。

B 78-0981. 72122, 33122

\title{
60. 副鼻膑気管支炎
}

\section{一一呼吸機能と咳嗽機転からの検討}

\section{○海野徳二・坂口幸作・矢島 洋 (和医大)}

副鼻胵気管支炎とは，副鼻腔炎と気管支炎とが合併し た状態をいら．これについては既に数多くの研究がなさ れているが，気管支炎の必発症状である咳に重点を拈い て検討を加えるのが本研究の目的である.

熱線流速計, Krogh 型スピロメーター, Body plethysmograph を使用して最大努力性呼気と意図的咳嗽を測 定した. 肺活量, 1 秒量, 1 秒率, 最大中間呼気速度, 最大 FV 曲線, 喛の FV 曲線, 咳の最大中間呼気速度に まとめて検討した，また最大FV曲線については，症例 間の比較が容易なように，肺活量の $75 \% ， 50 \% ， 25 \%$ に おける流速值 (それぞれ $\dot{V}_{75}, \dot{V}_{50}, \dot{V}_{25}$ ) や，それらの身 長による補正值 $\left(\dot{\mathrm{V}}_{75} / \mathrm{Ht}, \dot{\mathrm{V}}_{50} / \mathrm{Ht}, \dot{\mathrm{V}}_{25} / \mathrm{Ht}\right)$ をも計算し た. 16才から40才までの男子副粤腔炎患者20例に検查を 行つた.

各測定值はばらつきが大きかつたが，正常者と比較す ると一般に低い值をとる傾向にあつた．肺機能検查の 1 つとして広く用いられている䱋活量と 1 秒率とが80\%以 下の值を示したものは 3 例ずつあつた。最大中閒呼気速 度が 4LPS 以下の值を示したものは 7 例, $\dot{\mathrm{V}}_{50} / \mathrm{Ht}$ が 3L/S/M 以下となつたものは 6例で, この5ち5例は， 肺活量か 1 秒率のいずれかが80\%以下であつた. $\dot{V}_{25} / \mathrm{Ht}$ が1.5L/S/M 以下となつたものは13例に及んだ，咳の最
大中閶呼気速度が 4LPS 以下の值を示したものは10例 で,このうち9例壮 $\dot{\mathrm{V}}_{25} / \mathrm{Ht}$ 㔔 $1.5 \mathrm{~L} / \mathrm{S} / \mathrm{M}$ 以下の值をと つた例であつた。我々が以前に検查した正常例では，肺 活量や 1 秒率が80\%以下になることはなく, $\dot{\mathrm{V}}_{50} や \dot{\mathrm{V}}_{25}$ が低值を示すことも稀であつた。

呼気の速度は力を入れれば入れる程速くなるのではな い或る肺内空気量で出し得る最大の呼気速度は各人に ついて定まつている. 即ち $\dot{\mathrm{V}}_{75}, \dot{\mathrm{V}}_{50}, \dot{\mathrm{V}}_{25}$ などは，それ ぞれの肺内空気量に対応した最大の㭔気速度を意味す る.これ注速い呼気を出そらとして力を入れると，その

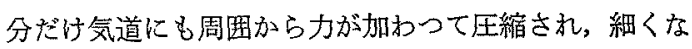
つてしまらことによる。これは一定以上の力を入れて呼 気を行った時に起る現象で，力を入れない呼気でもひと りでにこの速さが出るといらのではない咳も一種の力 強い呼気であるから，このようにして決つている最大速 度までは呼気速度が出せるはずである．実際に種々の肺 内室気量で咳をさせると，ピークの一過性に経過する部 分を除いては，最大 FV 曲線の下行脚亡，咳の FV 曲線 のそれとはよく重なり合らことが分つた，咳の呼出速度 が速いためには $\dot{\mathrm{V}}_{50} や \dot{\mathrm{V}}_{25}$ が大きいことが必要なので ある、一般の咳は，肺活量の 60-20\% 位の範囲で起つて いることが多いからである，咳の効率を決定する因子の 
1つとして，速さが重要な墈きを持つていることは閒違 いないから， $\dot{V}_{50} や \dot{V}_{25}$ の低下は咳の効率の低下と密接 な関倸があることになる．副鼻腔炎患者には $\dot{\mathrm{V}}_{50} や \dot{\mathrm{V}}_{25}$ の值, 特に $\dot{\mathrm{V}}_{25}$ の值が舆常に低いものが数多くみられ た. 他の検査方法では異常が認められない症例にも $\dot{V}_{25}$ の低値が認められたということは，この現象の一般的な 原因とされている細気管支の変化が, 副鼻腔炎患者では
既伦始まつているものと考えられる，汎細気管支炎の患 者に副䙹腔炎を合併する率が高いといら報告もこの事実 を示すものとして興味深い，咳の生理学的意義は，気道 から分泌物や異物を排除することにあるから，速さの減 少によつて咳の効率が覀くなると分泌物排泄障害につな がる，気道病変の慢性化や增悪化にも関連して副鼻腔気 管支炎成立の役割を担っているものと思われる.

B78-0982. 73022

\title{
61. アトロピン投与後の鼻粘膜刺激による肺 Compliance の変化
}

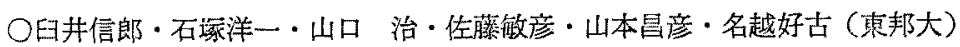

\section{目 的}

鼻粘膜に対する機禈的な刺激が下気道にどのような影 響を及ぼすかといつた点については，なおまだ論議があ る。われわれはすでに喉摘患者を対象に鼻と下気道の間 にみられる鼻粘膜刺激時の肺抵抗の变化学倠察し発表し たが，鼻粘膜刺激によつておこる肺 Compliance の変化 についても, Compliance が低下すると言っているもの, 変らないとするもの, あるいは值の変動が大きくて評価 出来ないとするものなどがあり，また気管支拡張郕の使 用で増加するといらものなど，いろいろな意見がある. そこで今回われわれは鼻と下気道の間に扔ける圧一気量 関係に及ぼす影響を，できるだけ直接的な方法で調べる ために上気道と下気道とが分離された状態にある喉摘者 を対象に，鼻粘膜に対する機械的な刺激がアトロピン投 与前・後において，肺 Compliance を指標としてみた場 合に、どの上うな影響を及ぼすかを調べることを目的と Lた.

\section{方 法}

被検者は50才から77才をでの喉頭全摘患者12人を対象 とした.

肺 Compliance と注安静呼吸時の食道内压, 気流速度 ならびに換気量を連続的に記録して求める Continuous cycling method によつた。 したがって求められる肺 compliance は dynamic compliance である。なお，同 時に鼻粘膜刺激時におこる下気道の圧と気流速度の变化 をみるための指標として肺粘性抵抗を求めた。

測定にあたつては被検者に坐位で気管切開口を通して 安静呼吸を枋こなわせながら，

1) 鼻粘膜刺激前の圧, 気流速度ならびに換気量を記
録した後,

2) 右鼻腔, ついで,

3）左鼾腔に中鼻道上り下鼻道にかけて鼻用綿棒で触 刺激を加えた場合,

以上について記録した.つぎに硫酸アトロピン $0.5 \mathrm{mg}$ の皮下注射を行い，25分後に再び同様の順序で刺激前・ 後の各呼吸曲線を記録した。

\section{結果と考察}

各被検者から得られた肺 Compliance の值は正常値に くらべて低かつた。これは拉そらく，喉摘の影響による 下気道の換気機能の低下や対象が高令者であつたことに よるものと考えられた。

肺 Ccmpliance の值は鼻粘膜刺激前・後でほとんど変 らず，またアトロピン投与後における鼻粘膜刺激でも明 汃な変化はみられなかつた．しかし，肺抵抗は刺激前の 状態よりる低下して扔り，またさらに，アトロピン投与 後の刺激によつても明らかな低下がみられることから， 多分, 鼻粘膜に対する機械的刺激は下気道の気管・気管 文領域に影響を及ぼすむのと考えられた。

質問 海野德二(和医大). 刺激に対して肺抵抗は影 響をらけるのにコンプライアンスが影響をうけないのは どのように侾えるか. 応答 曰井信郎（東邦大）１） 作用部位恃気管・気管支平滑筋と考えられる，2）鼻粘 膜刺潡に対する反店は P-V 曲線上ではわずかに変化す るが，統計学的には有意義な差はみられなかつた。

質問 今野昭義 (秋田大). 動物実験の結果からは鼻粘 膜一気管・気管支平滑筋反射の遠心路は副交感神経が主 であり，その tonus の変化にあると考えた．御発表の主 旨は交感神経の関与も大きいといら事であるらと思ら 